\title{
The Importance of Monitoring of Suspended Particles in the Ambient Air of the City of Niš
}

\author{
Ljiljana Stošić1,2, Dušica Stojanović1,2 \\ ${ }^{1}$ University of Niš, Faculty of Medicine, Niš, Serbia \\ ${ }^{2}$ Public Health Institute Niš, Niš, Serbia
}

\section{SUMMARY}

The aim of this paper was to show the results of monitoring of the concentration of suspended PM10 particles and heavy metals in the PM10 fraction in the City of Niš and to identify possible seasonal variations of PM10 concentrations in the same period. The goal was also to point out the importance of monitoring of these pollutants by reviewing the results of epidemiological studies that have investigated the impact of suspended particles on human health. Monitoring was carried out at one measuring point in the city, once a week, over a fiveyear period. It was found that the average annual concentration of $\mathrm{PM}_{10}$ was above the allowed values. Daily PM10 concentrations exceeded the limit and tolerant values in more than $50 \%$ of the measurements during the heating season. The studies conducted so far have indicated that particulate matter significantly affects the health of the exposed population (especially children, elderly, and people with heart or lung disease). The most common health consequences are inflammatory reactions of the respiratory system, decreased pulmonary function, damages to the cardiovascular system, changes in immunological response, frequent visits to the emergency medicine centers, as well as frequent hospitalizations.

Therefore, it is very important to continue monitoring of the concentration of these pollutants in accordance with the financial possibilities, to increase the number of measuring points and the dynamics of sampling. The assessment of the harmful impact is also important considering that no research has been carried out in Niš so far.

Key words: ambient air, particulate matter PM10, health outcomes

Corresponding author:

Ljiljana Stošić

E-mail: ljstosic@live.com 


\section{INTRODUCTION}

Air pollution with suspended particles is a major problem worldwide, including our country. The term suspended particles is used for substances that are contained in the air and consist of the particles or smaller liquid droplets. They represent a complex mix of organic and inorganic matter and may have different chemical com-position depending on the source of the emission. In general, suspended particles originate from natural and anthropogenic sources (1).

Natural sources are volcanic eruptions, desert storms, forest fires, sea salt spray, pollens, spores, plant fibers. They are harder to control and are usually left unregulated. However, human sources such as heating plants, traffic, industry, metal melting, agricultural areas can be regulated. On the other side, anthropogenic sources are more dangerous for health because they are smaller and penetrate deeper into the respiratory tract (2).

The chemical properties vary depending on the type of sources and significantly affect the degree of manifestation of negative health effects. Particles containing some toxic compounds such as heavy metals and polycyclic aromatic hydrocarbons may lead to more adverse effects for human health (3).

A classification of particles by size is better than by chemical properties. Particles less than or equal to 10 micrometers in diameter are so small that they can get into the lungs and cause potentially serious health problems. Negative effects on human health have raised the awareness of experts, regulatory bodies, and the public. Since 2010, Serbian regulations have prescribed monitoring of two fractions of particles in ambient air-PM2,5 and PM10.

Implementation of monitoring is very important for several reasons:

- improving the knowledge about particles in the air and their influence on health;

- planning and implementation of the measures that will lead to improvements in air quality at the local level;

- redefinition of regulations including limit values for suspended particles in the ambient air.

The aim of this paper was to show the results of monitoring of the concentration of suspended PM10 particles and heavy metals in the $\mathrm{PM}_{10}$ fraction in the City of Niš and to identify possible seasonal variations of
PM10 concentrations in the same period. The goal was also to point out the importance of monitoring of these pollutants by reviewing the results of epidemiological studies that investigated the impact of suspended particles on health.

\section{MATERIAL AND METHODS}

Measuring was carried out at one measuring point in the city, once a week, over one year. The measuring point was the Public Health Institute Niš, located in a wider city center without industry. This is the most important source of air pollution caused by road traffic (a big crossroads is at a distance of $150 \mathrm{~m}$, the nearest bus stop is $100 \mathrm{~m}$ away). A sampler of ambient air Mod MVS6, Sven Leck, Germany was used for sampling. Intake pipes and coresponding inputs for sampling PM10 were directly connected with filter substrate and a device for controlling the flow. Sampling of ambient air and laboratory testing were performed using the accredited methods and the test results were interpreted in accordance with the valid legislation.

The paper presents the average annual concentration in the five-year period (2013-2017), as well as the per cent of days with the values of pollutants above the allowed values and the average concentration of $\mathrm{PM}_{10}$ per season.

\section{RESULTS}

In the period from 2013 to 2017, the average annual concentration of PMio fraction of suspended particles was above the limit and tolerance value (Table 1). During the test period, an upward trend of average annual values of $\mathrm{PM}_{10}$ fraction of suspended particles was determined (Graph 1). Also, a large percentage of days with concentrations above the allowed values was recorded. The presence of an additional emission source (boiler room and individual firebox) during the heating season significantly influenced the increase in the concentration of suspended PM10 particles, so the average and maximum values were found to be significantly higher than the values after the heating season. Daily concentration of $\mathrm{PM}_{10}$ in more than $50 \%$ of the measurements in the heating season was above the limit values (Table 2). 
Table 1. Average annual values of PM10 and heavy metals in $\mathrm{PM}_{10}$ fraction $\left(\mu \mathrm{g} / \mathrm{m}^{3}\right)$

\begin{tabular}{c|c|c|c|c|c}
\hline \hline Year & $\mathbf{2 0 1 3}$ & $\mathbf{2 0 1 4}$ & $\mathbf{2 0 1 5}$ & $\mathbf{2 0 1 6}$ & $\mathbf{2 0 1 7}$ \\
\hline $\mathbf{P M} \mathbf{1 0}$ & 50.9 & 51.4 & 51.3 & 56.1 & 55.0 \\
\hline $\mathbf{P b}$ & 0.010 & 0.011 & 0.008 & 0.009 & 0.010 \\
\hline $\mathbf{C d}$ & 0.001 & 0.002 & 0.002 & 0.003 & 0.001 \\
\hline $\mathbf{A s}$ & 0.003 & 0.002 & 0.001 & 0.002 & 0.003 \\
\hline $\mathbf{N i}$ & 0.003 & 0.002 & 0.002 & 0.002 & 0.004 \\
\hline \hline
\end{tabular}

Trend of the fraction of suspended particles PM10 Public Health Institute Niš

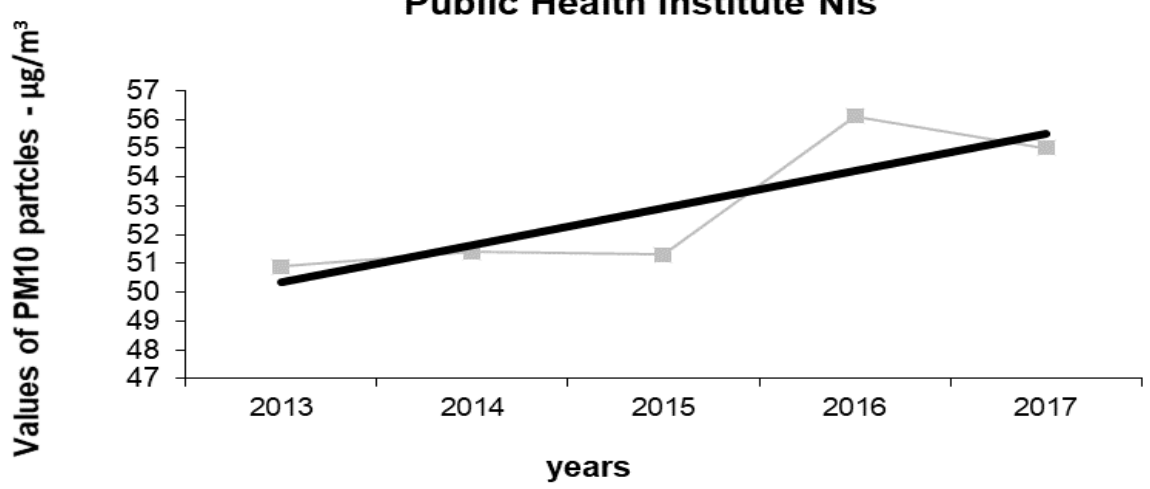

Graph 1.

Table 2. The concentration of PM10 during the heating and non-heating season in the period $2013-2017\left(\mu \mathrm{g} / \mathrm{m}^{3}\right)$

\begin{tabular}{|c|c|c|c|c|c|c|c|c|c|c|}
\hline \multirow[b]{3}{*}{ PM10 } & \multicolumn{10}{|c|}{ Public Health Institute Niš } \\
\hline & \multicolumn{2}{|c|}{2013} & \multicolumn{2}{|c|}{2014} & \multicolumn{2}{|c|}{2015} & \multicolumn{2}{|c|}{2016} & \multicolumn{2}{|c|}{2017} \\
\hline & $\begin{array}{l}\text { Heating } \\
\text { season }\end{array}$ & $\begin{array}{c}\text { Non- } \\
\text { heating } \\
\text { season }\end{array}$ & $\begin{array}{l}\text { Heating } \\
\text { season }\end{array}$ & $\begin{array}{c}\text { Non- } \\
\text { heating } \\
\text { season }\end{array}$ & $\begin{array}{l}\text { Heating } \\
\text { season }\end{array}$ & $\begin{array}{c}\text { Non- } \\
\text { heating } \\
\text { season }\end{array}$ & $\begin{array}{c}\text { Heating } \\
\text { season }\end{array}$ & $\begin{array}{c}\text { Non- } \\
\text { heating } \\
\text { season }\end{array}$ & $\begin{array}{c}\text { Heating } \\
\text { season }\end{array}$ & $\begin{array}{c}\text { Non- } \\
\text { heating } \\
\text { season }\end{array}$ \\
\hline $\mathbf{N}$ & 24 & 28 & 25 & 27 & 28 & 27 & 28 & 25 & 26 & 25 \\
\hline$X$ & 69.06 & 35.35 & 65.54 & 39.32 & 71.7 & 30.17 & 83.3 & 26.9 & 74.38 & 35.9 \\
\hline Median & 53.3 & 30.7 & 52.34 & 31.84 & 62.5 & 30.2 & 54.3 & 23.8 & 63.7 & 31.9 \\
\hline Min & 18.5 & 3.6 & 27.2 & 18.19 & 18.8 & 8.8 & 22.83 & 6.7 & 11.8 & 16.8 \\
\hline Max & 161.1 & 75.37 & 193.2 & 99 & 176.8 & 54.35 & 295.15 & 59.6 & 208.8 & 62.7 \\
\hline $\begin{array}{c}\text { Num (\%) } \\
\text { above } \\
\text { GV-daily }\end{array}$ & $14(58)$ & $2(7)$ & $14(56)$ & $5(18)$ & $15(54)$ & $2(7)$ & $15(54)$ & $2(8)$ & $21(80,7)$ & $2(8)$ \\
\hline
\end{tabular}




\section{DISCUSSION}

The concentrations of $\mathrm{PM}_{10}$ in the analyzed time period were significantly higher than the values prescribed by the current legislation. Also, increased values were found over a longer time period. Certain concentrations could have an impact on the health of the exposed population. The fact is that many polluting substances in the air, besides suspended particles, can adversely affect health. However, all previous studies (epidemiological studies and laboratory tests) indicate that particulate matter significantly affects the health of the exposed population (especially children, elderly, and people with heart or lung diseases).

The most important way of entering particles into the body is by inhalation. For this reason, health effects are primarily expressed on the respiratory system, and they include an increased prevalence of respiratory symptoms, decreased pulmonary function, increased hospitalization of patients due to respiratory diseases.

The deposition of particles in different parts of the respiratory tract is very complex and depends on the size of particles, breathing frequency, lung volumes and the state of health of the exposed person. Impaction is the most common way of deposition. When air passes through the airways, the direction of the air changes due to curvature, and particles, because of inertia, hit the walls of the airways (4).

In the United States, 153 cities across the country were tested for particle concentrations and their effects on the respiratory tract. It has been found that chronic exposure to the particles leads to an increased risk of chronic bronchitis and other respiratory diseases for each increase in the concentration of particles by $10 \mu \mathrm{g} / \mathrm{m}^{3}(5)$.

In the northern part of Mexico City, children with moderate degree of asthma were tested for particle concentrations and their effects on respiratory symptoms. The results showed that an increase in PM10 levels by 20 $\mu \mathrm{g} / \mathrm{m}^{3}$ leads to an increase in respiratory symptoms by $8 \%(6)$.

Increase in the concentration of PM particles can affect the frequent use of medicaments. A group of scientists found that the use of bronchodilators increased by $18.1 \%$ to $28.8 \%$ with the increase of $\mathrm{PM}_{10}$ from 34 to 61 $\mu \mathrm{g} / \mathrm{m}^{3}$ (7). A study conducted in China has shown that hospitalization for all respiratory diseases is growing with the increase of $\mathrm{PM}_{10}$ (8). A group of authors in Australia concluded that reducing the concentration of $\mathrm{PM}_{10}$ reduces the number of patients hospitalized due to respiratory diseases. Namely, they found that an increase of PMin particles by $10 \mu \mathrm{g} / \mathrm{m}^{3}$ increases hospitalization by $4 \%(9)$.

Based on the results of both epidemiological and laboratory studies, $\mathrm{PM}_{10}$ particles are also associated with a trend of increasing the number of allergic respiratory diseases (10).

Exposure to higher concentrations of PM particles may also be associated with adverse effects on the cardiovascular and cerebrovascular system in terms of more frequent hospitalization due to cardiovascular diseases and ischemic stroke (11-13). Although there are many significant risk factors for these diseases, the importance of PM particles should not be deminished, especially when considering a large number of people exposed to this pollutant every day.

\section{CONCLUSION}

According to these results, it can be seen how negative the impact of PM particles on the health of the exposed population is. On the other hand, the concentrations of $\mathrm{PM}_{10}$ in the analyzed time period were significantly higher than the values prescribed in the current legislation. For all these reasons, it is important to continue with further monitoring of the concentration of these pollutants in accordance with the material possibilities and to increase the number of measuring points and the dynamics of sampling. The assessment of the harmful impact is also important considering that no research has been carried out on the territory of the City of Niš so far. 


\section{References}

1. Eun JJ, Woo SL, Hyun YJ et al. Effects of particulate matter on respiratory disease and the impact of meteorological factors in Busan, Korea. Respr Med 2017; 124:79-87.

https://doi.org/10.1016/j.rmed.2017.02.010

2. Baldacci $S$, Maio S, Cerrai $S$ et al. Allergy and asthma: effects of the exposure to particulate matter and biological allergens. Resir Med 2015;109:1089104.

\section{https://doi.org/10.1016/j.rmed.2015.05.017}

3. Chang JH, Shin $\mathrm{CH}$, Kuan JB, Shau KH, Chin WH. Association of time-serial changes in ambient particulate matters (PMs) with respiratory emergency cases in Taipei,s Wenshan district.

4. Pražnikar ZJ, Pražnikar J. The effects of particulate matter air pollution on respiratory health and the cardiovascular system. Zdrav Var 2012; 51:190-9. https://doi.org/10.2478/v10152-012-0022-z

5. Pope CA, Bates DV, Raitzenne ME. Health effects of particulate air pollution: time for reassessment. Envir Health Perspect 1995; 103:472-80.

https://doi.org/10.1289/ehp.95103472

6. Romieu I, Meneses F, Ruiz S et al. Effects of air pollution on the respiratory health of asthmatic children living in Mexico City. Am J Respir Crit Care Med 1996; 154:300-7.

https://doi.org/10.1164/ajrccm.154.2.8756798

7. Chimonas MA, Gessner BD. Airborne particulate matter from primarily geologic, non-industrial sources at levels below (National Ambient Air Quality Standards is associated with outpatient visits for asthma and quick-relief medication prescriptions among children less than 20 years old enrolled in Medicaid in Anchorage, Alaska). Envron Res 2007; 103:397-404.

https://doi.org/10.1016/j.envres.2006.08.013
8. Xu Q Li X, Wang $\mathrm{S}$ et al. Fine particulate air pollution and hospital emergency room visits for respiratory disease in urban areas in Bejing, China, in 2013. 2016;11:e0153099. https://doi.org/10.1371/journal.pone.0153099

9. Meszaros D, Markos J, FitzGerald D, Walters E. Wood-Baker R. An observational study of PM10 and hospital admissions for acute exacerbations of chronic respiratory disease in Tasmania, Australia 19922002. BMJ Open Respir Res. 2015; 2: e000063. https://doi.org/10.1136/bmjresp-2014-000063

10. D,amato G, Cecchi L, D,amato M, Liccardi G. Urban air pollution and climate change as environmental risk factors of respiratory allergy: un update. J Investig Allergol Clin Immunol 2010; 20:95-102.

11. Jonathan $\mathrm{O}$, Anderson JG, Thundiyil. Clearing the air: A review of the effects of particulate matter air pollution on human health. J Med Toxico 2012; 8:166-175.

https://doi.org/10.1007/s13181-011-0203-1

12. Polichetti G, Cocco S, Spinali A, Trimarco V, Nunziata A. Effects of particulate matter ( $\left.\mathrm{PM}_{10}\right), \mathrm{PM}_{2,5}$ and $\mathrm{PM}_{10}$ on cardiovascular system. Toxicology 2009; 261:1-8.

https://doi.org/10.1016/j.tox.2009.04.035

13. Wellenius G. Shhwartz J, Mittleman M. Air pollution and hospital admissions for ischemic and hemorrhagic stroke among Medicare beneficiaries. Stroke 2005; 36:2549-53. https://doi.org/10.1161/01.STR.0000189687.78760.47 


\title{
Značaj praćenja koncentracija suspendovanih čestica u ambijentalnom vazduhu grada Niša
}

\author{
Ljiljana Stošić1,2, Dušica Stojanović1,2 \\ ${ }^{1}$ Univerzitet u Nišu, Medicinski fakultet, Niš, Srbija \\ ${ }^{2}$ Institut za javno zdravlje Niš, Niš, Srbija
}

\section{SAŽETAK}

Cilj ovog rada bio je da prikaže rezultate praćenja koncentracije PM10 čestica i teških metala u frakciji PM10 u gradu Nišu i da utvrdi potencijalne sezonske varijacije koncentracija u istom periodu. Cilj je, takođe, bio da se ukaže na značaj praćenja ovih zagađujućih materija u vazduhu kroz prikaz rezultata epidemioloških studija koje su pratile uticaj različitih koncentracija PMı na zdravlje izloženog stanovništva. Praćenje koncentracija izvršeno je na jednom mernom mestu u gradu, jednom nedeljno, tokom petogodišnjeg perioda. Utvrđeno je da su prosečne godišnje vrednosti PM10 čestica bile više od dozvoljenih. Dnevne koncentracije $\mathrm{PM}_{10}$ su u više od $50 \%$ merenja, u sezoni loženja, premašivale graničnu vrenost. Rezultati epidemioloških studija pokazuju da suspendovane čestice značajno utiču na zdravlje izloženih, a posebno dece, starijih osoba i hroničnih bolesnika. Najčešće zdravstvene posledice su inflamatorne reakcije respiratornog sistema, smanjenje plućne funkcije, oštećenja kardiovaskularnog sistema, promene u imunološkom odgovoru, što dovodi do češće posete hitnoj službi, kao i češće hospitalizacije. Veoma je važno nastaviti dalje praćenje koncentracija ovih zagađujućih materija, povećati broj mernih mesta $\mathbf{i}$ dinamiku uzorkovanja, u skladu sa materijalnim mogućnostima, i uraditi procenu uticaja na zdravlje izloženog stanovništva. Procena štetnog uticaja na zdravlje izloženog stanovništva takođe je važna s obzirom na to da do sada u Nišu nisu urađena takva istraživanja.

Ključne reči: ambijentalni vazduh, suspendovane čestice PM10, zdravstvene posledice 